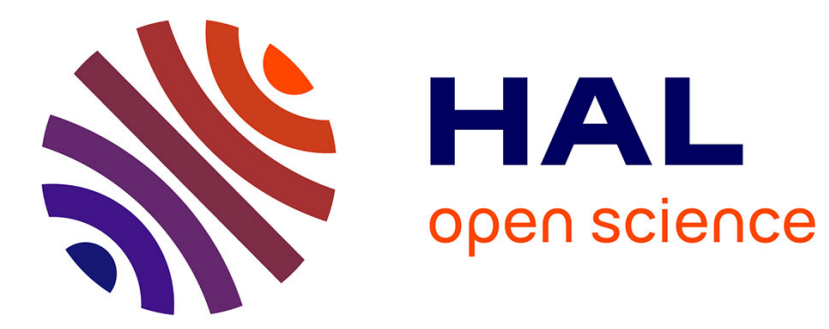

\title{
ANALYTICAL APPLICATIONS OF TIME-RESOLVED LASER-INDUCED FLUORESCENCE IN THE NUCLEAR FUEL CYCLE
}

C. Moulin, P. Decambox, P. Mauchien

\section{- To cite this version:}

C. Moulin, P. Decambox, P. Mauchien. ANALYTICAL APPLICATIONS OF TIME-RESOLVED LASER-INDUCED FLUORESCENCE IN THE NUCLEAR FUEL CYCLE. Journal de Physique IV Proceedings, 1991, 01 (C7), pp.C7-677-C7-680. 10.1051/jp4:19917182 . jpa-00250861

\section{HAL Id: jpa-00250861 https://hal.science/jpa-00250861}

Submitted on 1 Jan 1991

HAL is a multi-disciplinary open access archive for the deposit and dissemination of scientific research documents, whether they are published or not. The documents may come from teaching and research institutions in France or abroad, or from public or private research centers.
L'archive ouverte pluridisciplinaire HAL, est destinée au dépôt et à la diffusion de documents scientifiques de niveau recherche, publiés ou non, émanant des établissements d'enseignement et de recherche français ou étrangers, des laboratoires publics ou privés. 


\title{
ANALYTICAL APPLICATIONS OF TIME-RESOLVED LASER-INDUCED FLUORESCENCE IN THE NUCLEAR FUEL CYCLE
}

\author{
C. MOULIN, P. DECAMBOX and P. MAUCHIEN \\ CEA/DCC/DPE/SPEA/SPS/Analytical Laser Spectroscopy Laboratory, BP. 6 , \\ F-92265 Fontenay aux Roses, France
}

\begin{abstract}
Time Resolved Laser-Induced Spectrofluorometry (TRLIS) is a very sensitive and selective method that has been used for actinides and lanthanides analysis in the nuclear fuel cycle. This technique has been used in different fields such as in geology, in the Purex process, in the environment, in the medical and in waste storage assessment. Spectroscopic data ( $\lambda$ excitation, $\lambda$ emission, lifetime), limits of detection and results obtained in previously quoted fields are presented.
\end{abstract}

\section{Introduction}

Fast and sensitive methods are still required in the nuclear fuel cycle for ultratrace determinations of actinides and lanthanides. Time-Resolved Laser-Induced Spectrofluorometry (TRLIS) is a method of choice for such determinations and has been used for now more than 10 years at the CEA. The principle of this technique consists in pulsed laser excitation followed by temporal resolution of the fluorescence signal which leads to the elimination of unwanted short lifetime fluorescence (organic matters, Raman). The main advantage of TRLIS aside rapidity and sensitivity is its triple selectivity. Excitation selectivity by the proper choice of the laser excitation wavelength, emission selectivity since each fluorescent element gives a characteristic fluorescence spectrum and finally time resolution selectivity which characterizes the fluorescent element environment. Among the actinides and lanthanides, the ones that are fluorescent in solution are uranium, curium, americium and europium, terbium, dysprosium, samarium, gadolinium, cerium, thulium. These elements have been studied in different complexing media (nitric, phosphoric, sulphuric, carbonate, micellar) and analysed from the part per billion $\left(10^{-6} \mathrm{~g} / \mathrm{l}\right)$ to the part per trillion $\left(10^{-9} \mathrm{~g} / \mathrm{l}\right)$ and lower $/ 1-4 /$.

The different fields of interest in the nuclear fuel cycle where TRLIS has been used are in :

- Environment control for uranium determination in water and soil samples in order to have a "cartography" of specific areas ;

- Geology, for ultratrace determination of uranium (ng/l level) in waters from different localities in order to obtain a better understanding of uranium mobilization under natural reducing conditions and so to validate thermodynamic data $/ 5 /$;

- All the different steps of the Purex process, in plutonium matrices for quality control, in organic matrices (TBP, TPH) where uranium used as tracer allows to calculate decontamination factors of new installations and hence to ameliorate performances of the process ;

- Medical surveillance for direct and fast determination of uranium in human urines. Hence, based on the uranium concentration in urine, metabolic models are established to estimate the body burden of uranium from persons exposed to uranium ambience $/ 6 /$;

- Waste storage assessment, for the determination of complexing constants at very low level between actinides and organic matters. TRLIS allows to work directly at trace level and has been applied to curium $/ 7 /$.

Moreover, in Purex process control, TRLIS remote measurements are performed in hot cell with the adaptation of fiber optics and optode. 


\section{Material and Methods}

Apparatus: The experimental set-up is schematically shown in Figure 1.

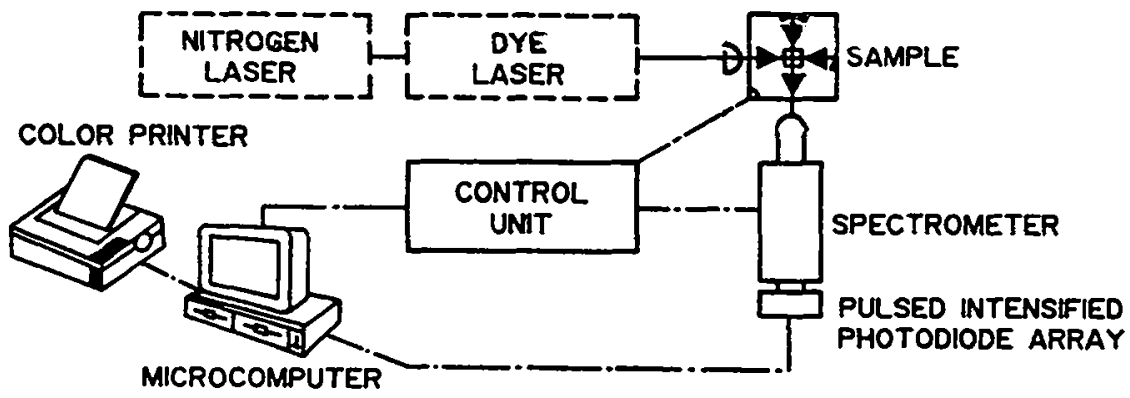

Figure 1 : TRLIS experimental set-up.

A laser $\left(\mathrm{N}_{2}(337 \mathrm{~nm})\right.$, excimer $(308 \mathrm{~nm})$ or Nd-YAG $(355 \mathrm{~nm})$ ) coupled or not with a dye laser is used as excitation source. The laser beam is focused into the cell of the spectrofluorometer "FLUO $2001^{\prime \prime}$ (DILOR) by a quartz lens. The radiation coming from the cell is focused on the entrance slit of the monochromator (range covered $200 \mathrm{~nm}$ ). The detection is performed by an intensified photodiodes (512) array cooled by Peltier effect and positioned at the monochromator exit. Recording of spectra is performed by integration of the pulsed light signal given by the intensifier. The integration time adjustable from 0.1 to $30 \mathrm{~s}$ allows for variation in detection sensitivity. Timeresolution is obtained by the control unit that assures pulsed running of the intensifier and the photodiodes array. Measurements are adjustable with a delay from 1 to $999 \mu$ s during a time of 1 to $99 \mu \mathrm{s}$. All functions of the apparatus (temporal delay, gate width, integration time, reading of spectra, ...) are controlled by a PC-AT microcomputer. Analytical software automatically calculates concentrations by the standard addition or the initial fluorescence methods.

\section{Performances}

Table 1 presents convenient excitation and main emission wavelengths, limits of detection and lifetimes in best complexing media for the different fluorescent actinides and lanthanides in solution.

\begin{tabular}{l|l|c|l|c|l} 
Elt & $\lambda_{\text {exc }}(\mathbf{n m})$ & $\lambda_{\text {em }}(\mathbf{n m})$ & LoD $(\mathbf{M})$ & Lifetime $(\mu \mathrm{s})$ & Medium \\
\hline $\mathrm{U}$ & 337,420 & $494-514-545-565$ & $5.10^{-12}$ & 200 & $\mathrm{H}_{3} \mathrm{PO}_{4}$ \\
$\mathrm{Cm}$ & 337,385 & 612 & $4.10^{-13}$ & 200 & TTA/Triton \\
$\mathrm{Am}$ & 507 & 697 & $5.10^{-9}$ & 0.03 & $\mathrm{~K}_{2} \mathrm{CO}_{3}$ \\
$\mathrm{Eu}$ & 337,394 & $590-617-650-690$ & $10^{-12}$ & 900 & TTA $/ \mathrm{Triton}$ \\
$\mathrm{Tb}$ & $337,355,380$ & $490-545-590-625$ & $10^{-9}$ & 2100 & EDTA \\
$\mathrm{Sm}$ & $337,355,380$ & $565-600-650-710$ & $10^{-10}$ & 80 & TTATOPO \\
$\mathrm{Dy}$ & 355,390 & $485-580-670$ & $10^{-10}$ & 20 & EDTA \\
$\mathrm{Ce}$ & 260 & 360 & $10^{-9}$ & 5.07 & $\mathrm{H}_{2} \mathrm{SO}_{4}$ \\
$\mathrm{Gd}$ & 275 & 313 & $5.10^{-8}$ & 3000 & $\mathrm{H}_{2} \mathrm{SO}_{4}$ \\
$\mathrm{Tm}$ & 360 & 455 & $5.10^{-6}$ & 7 & $\mathrm{~K}_{2} \mathrm{CO}_{3}$
\end{tabular}




\section{Results}

In the environment, determination of uranium and curium at ultra low level are required for cartography purposes. Figure 2 and 3 respectively represents the fluorescence spectrum of uranium at $2 \mathrm{ng} / \mathrm{l}$ and curium at $0.2 \mathrm{ng} / 1$ in appropriate complexing media. This last value for curium, roughly corresponds to $10^{7}$ molecules in the interaction volume.

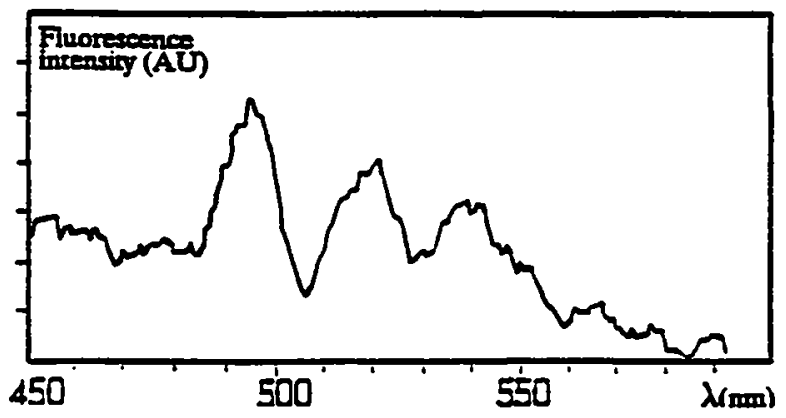

Figure 2. Fluorescence spectrum of uranium $\left(10^{-11} \mathrm{M}\right)$ in phosphoric acid.

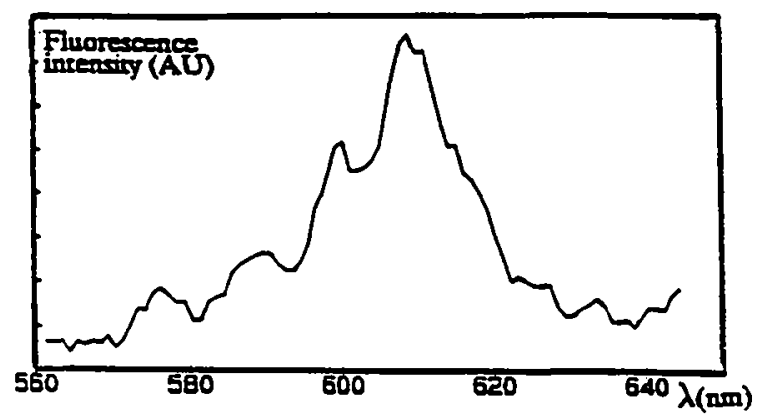

Figure 3. Fluorescence spectrum of curium $\left(9 \cdot 10^{-13} \mathrm{M}\right)$ in TTA/TOPO/Triton X100.

In the Purex process and for example in the TEO (Organic Waste Treatment) project where the main goal was to determine the decontamination factor (DF) of an installation by using uranium as tracer in the organic phase (TBP, TPH) to simulate radioactive elements behaviour. The DF factor simulated by calculation was expected to be in the $10^{3}$ to $10^{4}$ range. The uranium initial concentration in the feeding was set to $10 \mathrm{mg} / \mathrm{l}$ and practical measurements by TRIIS in the concentrate in the $\mu \mathrm{g} / 1$ to sub $\mu \mathrm{g} / \mathrm{l}$ have confirmed previously quoted figures. These data have allowed to visualize effects of eventual modifications of the installation on the decontamination factor.

In waste storage assessment, the knowledge of radioelement behaviour is of great importance. In particular, complexation reactions of radioelements with natural organic ligands such as humic substances (humic/fulvic acids) present in aquifer systems are important, because of the strength of complexes that humic substances form with cations, in particular trivalent elements like americium and curium. TRLIS is the only technique that allow to work directly at trace levels. The complexation of curium by humic substances leads to an increase of the curium fluorescence signal until saturation of the complexing sites occurs. From titration curves, binding parameters such as the complexing capacity $W$ and the conditional stability constant $\beta$ are obtained. 


\section{Conclusion}

Time-Resolved Laser- Induced Spectrofluorometry is a fast, sensitive and selective technique for uranium determinations in the nuclear fuel cycle. These features have allowed to use TRLIS in various fields from ultratrace analysis to complexation studies. Other elements such as curium, americium and several lanthanides can also be analysed. Furthermore, the use of fiber optics and optodes allow remote measurements in hostile environment and seems promising for in-line analysis in the nuclear fuel cycle.

\section{References}

1. P. Mauchien, P. Decambox, C. Moulin, T. Berthoud, B. Kirsch. Direct uranium trace analysis in plutonium solutions by Time-Resolved Laser-Induced Spectrofluorometry. Anal. Chem. 60, 1296 (1988).

2. P. Mauchien, P. Decambox, C. Moulin, T. Berthoud, B. Kirsch. Direct determination of traces of lanthanides ions in aqueous solution by Laser-Induced Time-Resolved Spectrofluorometry. Anal. Chim. Acta. 220, 235 (1989).

3. C. Moulin, P. Decambox, P. Mauchien. Time-Resolved Laser-Induced Fluorescence for curium trace determination. Radiochim. Acta. 48, 23 (1989).

4. C. Moulin, P. Decambox, P. Mauchien. Part per quadrillion determination of curium in micellar medium by Time-Resolved Laser-Induced Spectrofluorometry. Anal. Chim. acta. In press.

5. C. Moulin, C. Beaucaire, P. Decambox, P. Mauchien. Determination of uranium in solution at the ngl/1 by Time-Resolved Laser-Induced Spectrofluorometry : application to geological survey. Anal. Chim. Acta. 238, 291 (1990).

6. C. Moulin, P. Decambox, P. Mauchien. Direct and fast determination of uranium in human urines by Time-Resolved Laser-Induced Spectrofluorometry. Appl. Spec. 45, 116 (1991)

7. C. Moulin, P. Decambox, P. Mauchien, V. Moulin, M. Theyssier. On the use of Time-Resolved Laser-Induced Spectrofluorometry for interaction studies between organic matters and actinides : application to curium. Radiochim. Acta. 52/53, part 1, 119 (1991). 